\title{
AN HISTORICAL SURVEY ON THE EVOLUTION OF SOME FOREST WATERSHED MANAGEMENT TECHNIQUES (PART II: STREAM CHANNEL WORKS)
}

\author{
Elena Bresci, Federico Preti
}

\section{Introduction}

Historical surveys on the utilization of works, nowadays classified as belonging to soil bioengineering, are recently of growning interest [Preti 2004; Anselmo 2008; Bischetti 2008; Evette 2009]. The aim of this article was to complete the previous Part I [Bresci 2002], using a historical perspective focused exclusively on conventional and bioengineering techniques applied to streams and rivers.

Based on an available bibliography, this article examines the different forms of techniques used in the past to manage rivers and riverbanks, mainly using living material. The carried out survey originated by the examination of some old texts belonging to the Department of Agricultural and Forest Engineering library (today Department of Agricultural and Forest Economics, Engineering, Sciences and Technology, Division of Agricultural and Forest Biosystems Engineering) and some others from the personal library of Prof. Grazi. Some texts have been mentioned because some other articles quoted them. Only some works have been selected among those utilized for streambank protection for brevity needs. The original quotations in Italian have been translated into English and here synthesized and reported, in a chronological order, to allow the comparison with the description found in the Schiechtl manual [1991], considered as the reference book for soil bioengineering interventions. They are available and they will be presented in a paper in progress.

\section{Materials and methods}

\subsection{Vegetated streambank protection}

Schemerl in 1818 [Anselmo 2008] reported the use of fascines for streambank protection, sometimes filled

Paper received 23.10.2009; accepted 19.08.2010

Prof. ElENA BRESCI Associate Professor (elena.bresci@unifi.it), Prof. Federico Preti Associate Professor Dipartimento di Economia, Ingegneria, Scienze e Tecnologie Agrarie e Forestali Sezione di Ingegneria dei Biosistemi Agrari e Forestali Università degli Studi di Firenze, Piazzale delle Cascine, 18 - 50144 Firenze with gravels. He continues stating that the main aim of the fascine use is represented by their attitude to reduce flow velocity. They are flexible and adaptable; he expresses some doubts on the rigid work utilization realized with posts, preferring then the fascines.

Valentini [1893] suggests the use, as finishing works, of wattlings and the fascines. The first class wattles $(1.5 \mathrm{~m}$ high) are made up of posts vertically driven into the soil on a line normal to the torrent. Those posts are of two different orders: the first in larch are bigger and located at a distance of $1 \mathrm{~m}$, the second order in willow, at a distance of $33 \mathrm{~cm}$, and able to germinate. Willow twigs are weaved on the posts.

Lanino in 1898 [Anselmo 2008] reported some indications regarding stream defence works on the plain, saying that the riverbank revetment can be made by masonry, but the experience showed that it is preferable, for effectiveness and economic reasons, the utilization of wood, as planting, fascines, wattles, very often combined together; these woods, such as willow, alder, poplar, in contact with water germinate and, in a short time, develop a thick vegetation, able to raise an elastic resistance to the flow much more efficacious than the rigid resistance offered by the masonry works, against which the water hits on and excavates. When, under particular conditions of soil and climate, the vegetation works are not able to root, gabions filled with stones, may be utilized. Those gabions are realized intertwining branches or wires.

Another indication comes from Wang [1903] and refers to the height of the defence work, this height should in fact exceed the maximum level of the flood. Moreover, regarding the execution suggestions, he says that attention should be kept on the side walls to avoid the turning. The same text proposes the material to be chosen for bank protection works as a function of the local characteristics. In fact, where the local conditions, such as weak river slope and low solid discharge, vegetated works are favourable and utilized. In mountain creek, masonry and stone works are preferable.

Among the more common types, he mentions wattles, fascines and flexible cylinders, which are cylinders of vegetative fascines filled with gravels and tied 

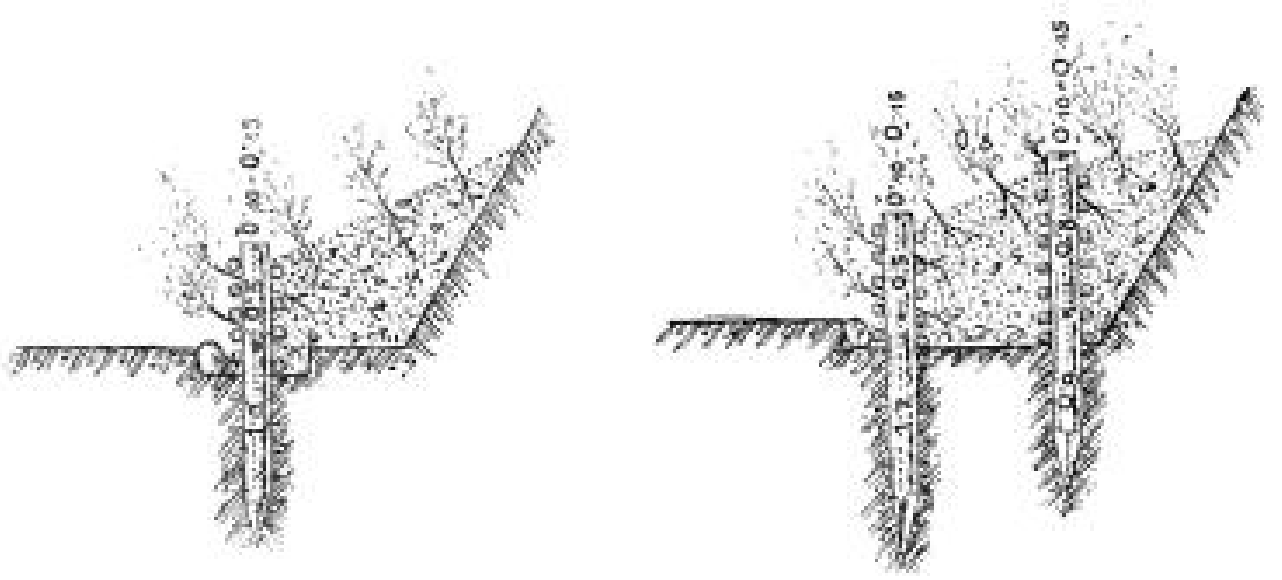

Fig. 1 - Wattles [Wang 1903].

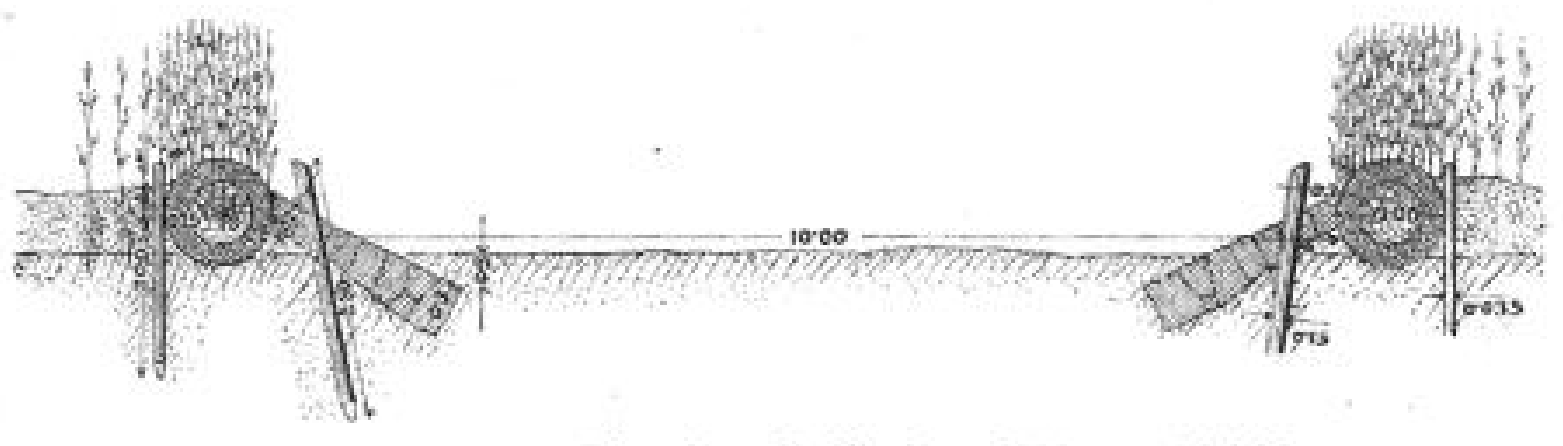

Fig. 2 - Cylinders [Wang 1903].

with wire, for which he gives suggestions on the dimensions. A cylinder has a total thickness of roughly $1 \mathrm{~m}$ and a length given by the portion of riverbank to be protected. If it is necessary, more cylinders can be put on the same bank. Fixed poles show the riverbank line and protect the cylinders from shifting. Stones can be utilized against the flow scouring.

Among the cylinder advantages, Wang outlines the possibility of realizing vegetated streambanks and, thanks to their weight, of filling the water dug holes. Their use is recommended for torrents or rivers having a gentle slope and transporting small gravels.
Piccioli [1905] maintains that riverbanks can be protected using tree trunks placed one upon the other, parallel to the flow direction and blocked with other trunks vertically driven. More often, wattles, fascines or cuttings are used.

Valentini in 1912, within the longitudinal defence works, mentions the wattles, the timber walls and, where necessary, the wooden guide wall.

Viappiani [1923] advises to utilize, as streambank defence works, those which are able to mitigate the impetuousness of the river flow and the consequent erosive action. He suggests methods allowing the
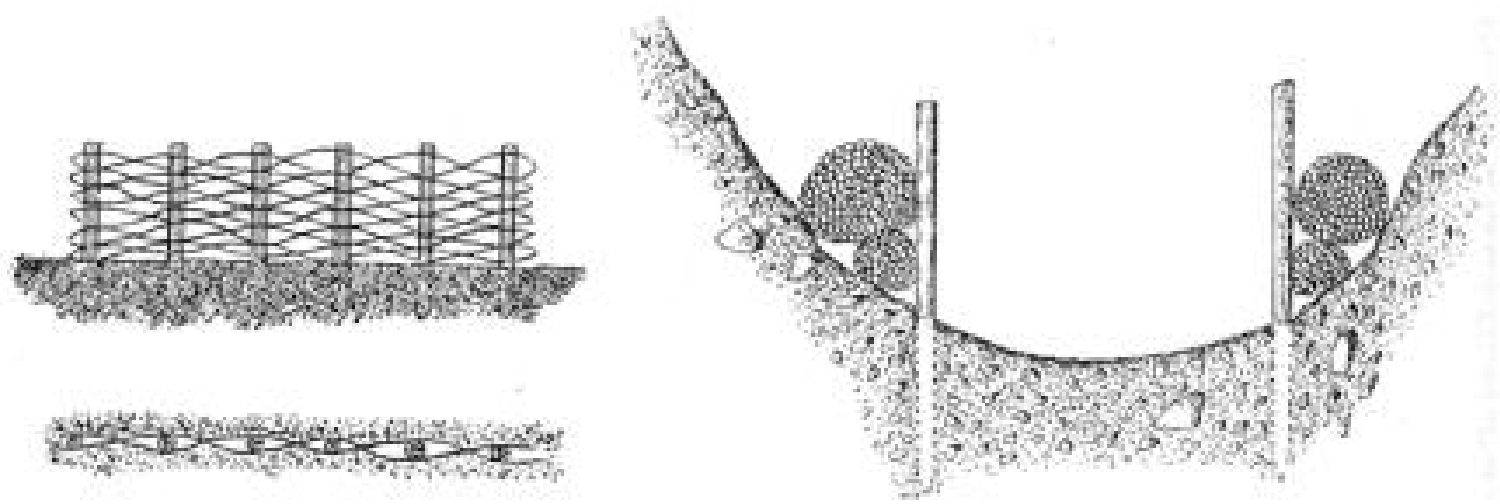

Fig. 3 - Wattling and fascines [Piccioli 1905]. 
revetment with vegetation. The grating with seed (willow and alder) is also able to consolidate the riverbank with the roots and to favour the deposition of solids during muddy flood events. He suggests also the use of a set of fascines, laid out along the direction of the maximum slope of the streambank, fixed to posts located at a distance of $0.5-1 \mathrm{~m}$. The fascines are tied up together and to the posts.

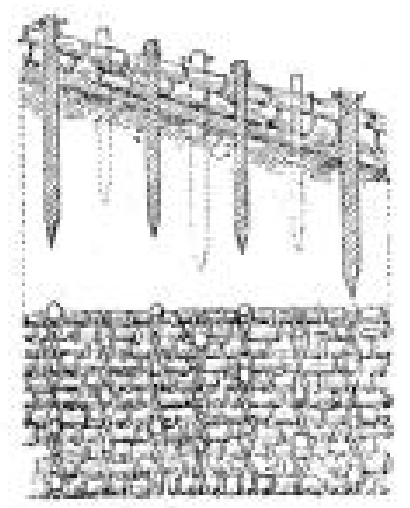

Fig. 4 - Set of fascines [Viappiani 1923].

Hofman [1936] reports as examples of longitudinal defence works walls, cobble-stones, revetment with wood, tipped stones, fascines, wattles, and where possibile a revetment of lying turf or fascines.
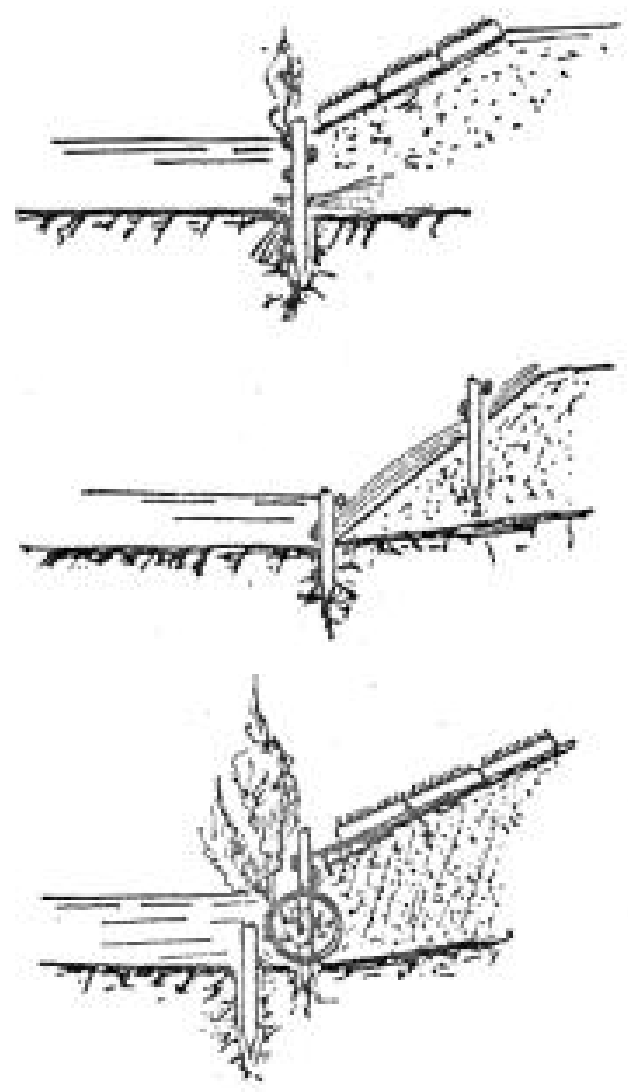

Fig. 5 - Streambank protection works [Hofman 1936].
Di Tella [1939] suggests the use of a double row of wattlings or longitudinal fascines to protect streambanks from scours.

\subsection{Revetment with cuttings}

Wang [1903], in the wattling description, adds that the revetment with vegetating materials of the portion between two wattles would offer a better result for the protection work. This method can be applied where there is abundance of vegetative materials and the conditions for their rooting. He reports the method utilized by Ludwig Seeling for the control of a torrent in Galizia, through a system of parallel works and small dams. The parallel structures are formed by rows of posts $1.5 \mathrm{~m}$ long and $8 \mathrm{~cm}$ diameter, driven into the ground for $1 \mathrm{~m}$ and at $1.3 \mathrm{~m}$ intervals. A second row of longer posts are driven upstream. The space between the posts is filled with branches of different dimensions and fixed by perches located crosswise allowing the perches to touch the ground. The embankment is covered by surface soil to avoid that the branches parch. A great advantage of this method is offered by the consolidation action offered by the root presence; a disadvantage is the utilization of a great quantity of material for fascines. It is then not utilizable in places where such a quantity of material is not available. It also not advisable in streams where there is abundance of gravels.

Another reference to the brush mattress is given by Viappiani [1923], that proposes the use of those species that are water resistant. These works are preferable to those realized with inert materials for riverbank protection.

Hofman also [1936] suggests the revetment of river banks through a simple turfing or, better, brushing when the river flow is not able to hit them.

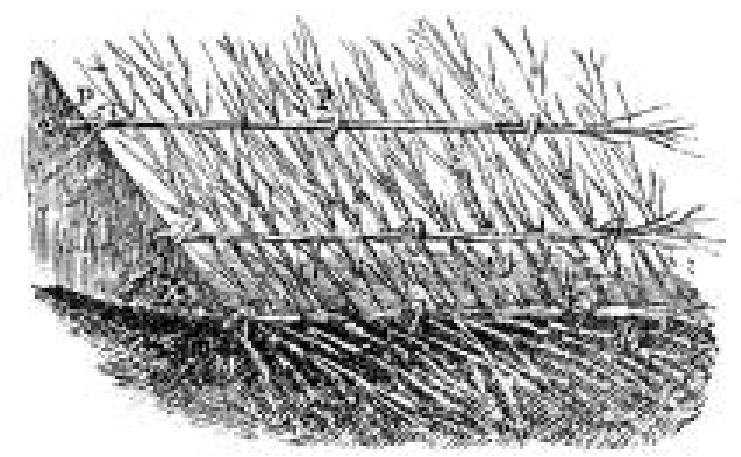

Fig. 6 - Brush mattress [Viappiani 1923].

Nowadays, Schiechtl [1991] proposes an accurate description of the construction works, particularly, of the operations required to correctly position the stakes to cover the streambank. It is important to ensure the stakes to take root and avoid the possibility of being uncovered. 


\subsection{Groynes}

Alberti in 1799 [Anselmo 2008] reported the opinion of Bernardino Zendrini regarding the damages on groynes realized by log rock crib, due to the scour and the vortex around the anchor log. Zendrini suggests utilizing a section as in figure 7 .

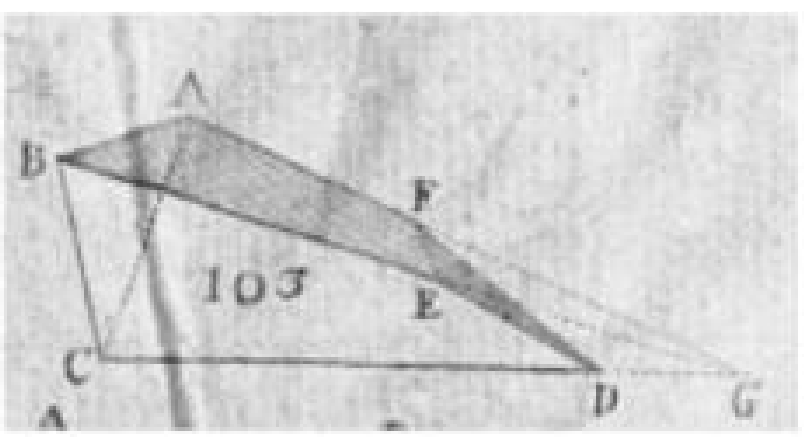

Fig. 7 - Groynes [Alberti in Anselmo 2008].

Alberti also [Anselmo 2008] proposed a detailed description of a groyne construction (fig. 8). Posts of willow or poplar are driven in rows, starting from the point where the erosion begins (point $\mathrm{B}$ ); that row is inclined with respect to the flow. Those posts should not be too high and they decrese in height going away from the riverbank. They are driven one close to the other and linked with willow twigs. Rows of posts are realized with different slopes as $\mathrm{CD}, \mathrm{EF}, \mathrm{GH}$. They may be also connected with hedges (IK, LM) to increase the stability and favour the material deposition. The portion between two contiguous hedges can be also filled with vegetative material.

In 1818 Schemerl [Anselmo 2008] described groynes of great dimensions, entirely realized with fascines. In particular, 5148 fascines were utilized for the realization of a groyne of $970 \mathrm{~m}^{3}$ volume.

A construction method for groynes has been proposed by Wolf [1888] for the Isar (Baviera) control as reported by Wang [1903]. It consists in posts, with a diameter of $20-25 \mathrm{~cm}$, driven in the river bed at a distance of $3 \mathrm{~m}$ from the future riverbank line. To those posts, located at a distance of $2.5 \mathrm{~m}$ one from the other and arriving up to a 3-5 $\mathrm{m}$ depth in the riverbed, are linked fascines using wooden poles and iron wires. The fascines are located at the low water level. Such a disposition contributes to the settling of the fine material increasing the consolidation of the riverbank.

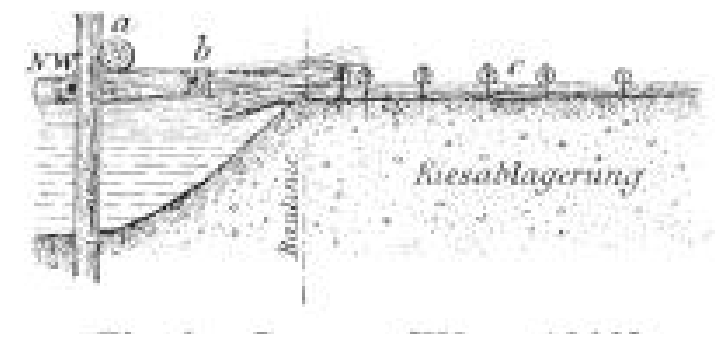

Fig. 9 - Groynes [Wang 1903].

Wang [1903] also asserts that the so-called "groynes" are seldomly utilized in mountain streams characterized by high slopes. The construction typology strongly depends on groyne function. Still Wang refers to Demontzey, who reports an example of streambank defence through rams made with bamboo bask.

Piccioli [1905] maintains the groynes' use for torrent bank defence to deviate the water from the bank. They may be realized with stones or a combined structure of wood and stones. In this case, posts, poles and brushwood are utilized. The head of the groyne may be realized normal to the flow or with an angle downstream or upstream depending on the correction effect.

Viappiani [1923] does not give precise indications on the distances among groynes, because he asserts that fixed rules cannot be given; in fact only one groyne was enough to protect a $400 \mathrm{~m}$ portion of river bank. He specifies the necessity of monitoring and maintenance to ensure a good functioning of the

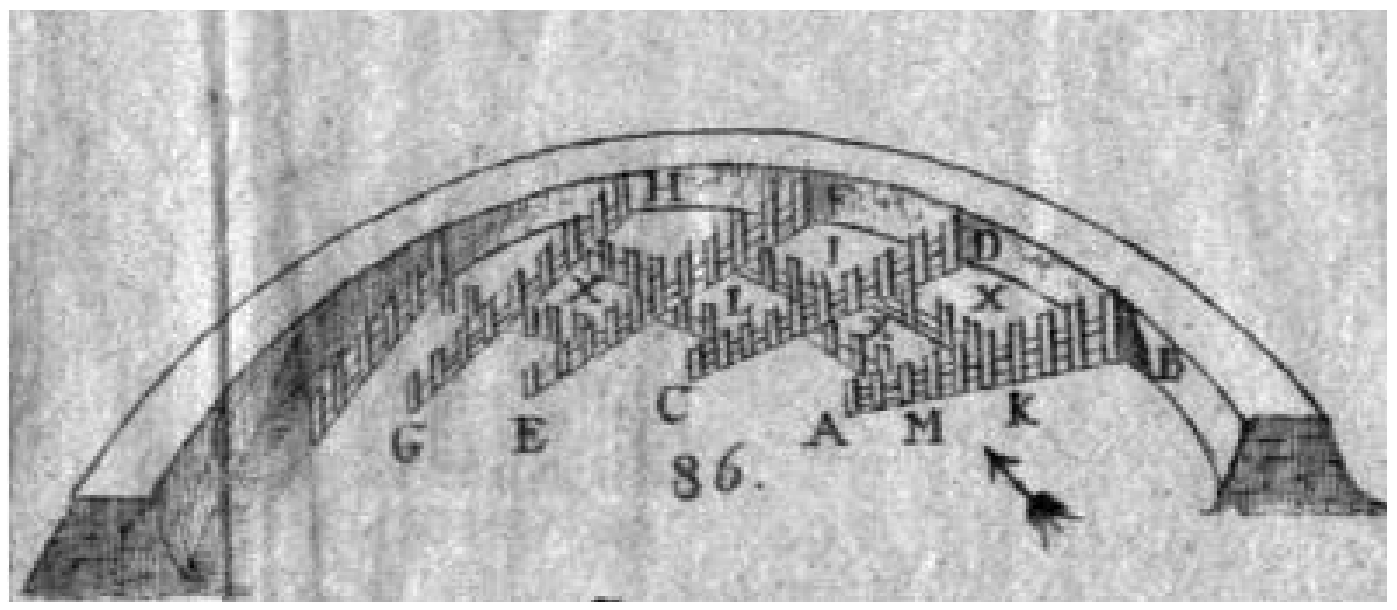

Fig. 8 - Groynes description [Alberti in Anselmo 2008]. 

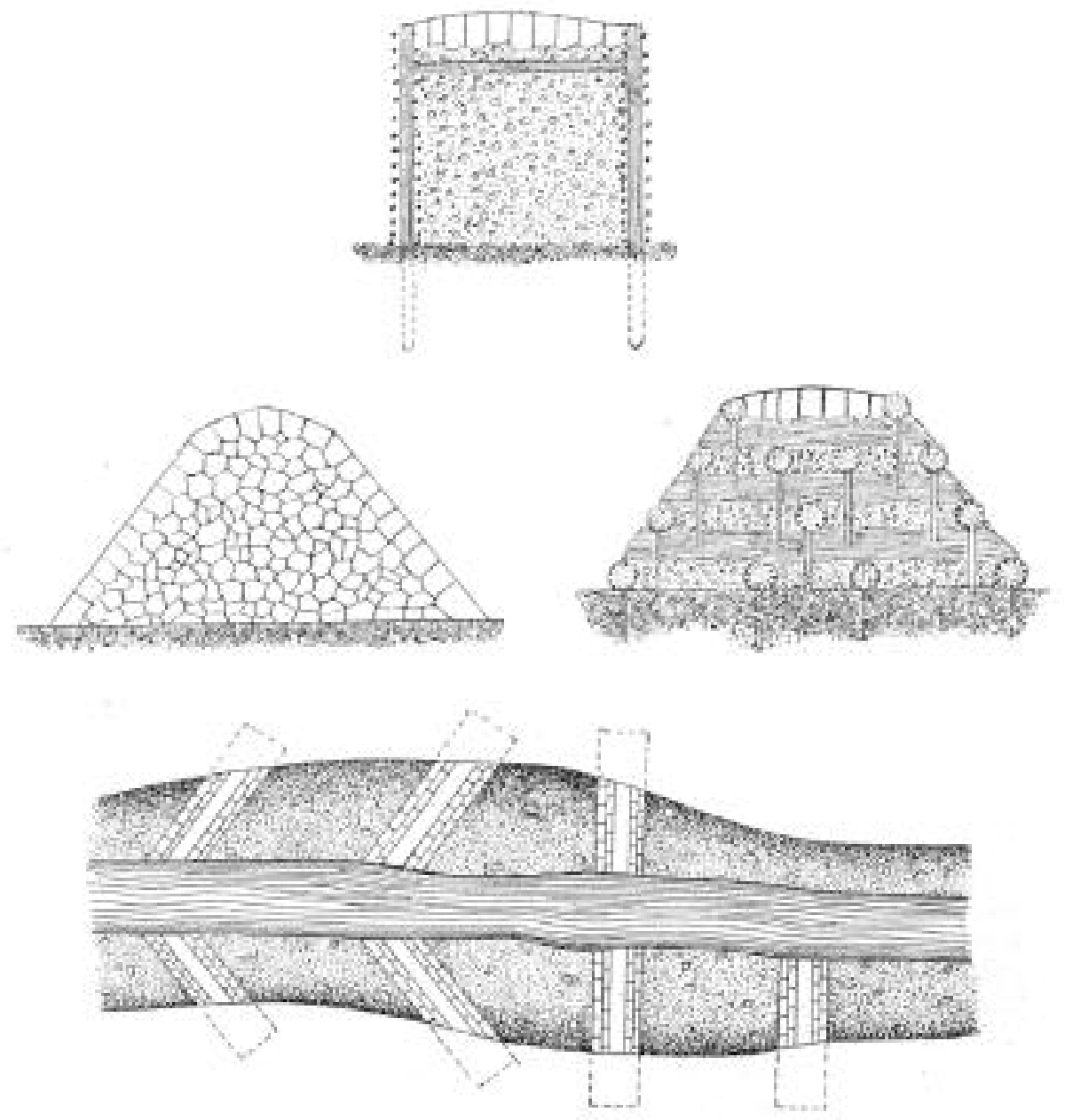

Fig. 10 - Groynes [Piccioli 1905].

groynes. In fact, he continues saying that such protection works need to be visited, in particular, after flood events, both for verifying good functioning and eventual deficiencies, if present, because carelessness could induce the inefficiency of the protection work, requiring high cost repairing.

Hofman [1936] suggests the utilization of groynes in streams characterized by a gentle slope and regular discharge. Among the construction typology, he refers both to gabions in metal mesh which are not able to resist to torrential floods and then used in floods with low sediment transport and to the fascines with gravels and fixed to avoid water to lift and bend.

Di Tella [1939] stresses the necessity of groynes to be well anchored to the banks and with an adequate foundation and eventually realizing riprapping close to the groyne head to control the erosion due to vortex formation. He gives also indications on the spatial defence action of groynes, equal to $5 \mathrm{a}$, if a is the protrusion of the groyne in the riverbed, because in that reach the flow is characterized by a moderate erosive action. As construction modality, he proposes a series of tree trunks placed one upon another embedded in the riverbanks, interposed with fascines. Grazi [1980] suggests that the distance between two groynes should not be able to originate high velocity in the intermediate reach (empirically established equal to 3-4 times the protrusion).
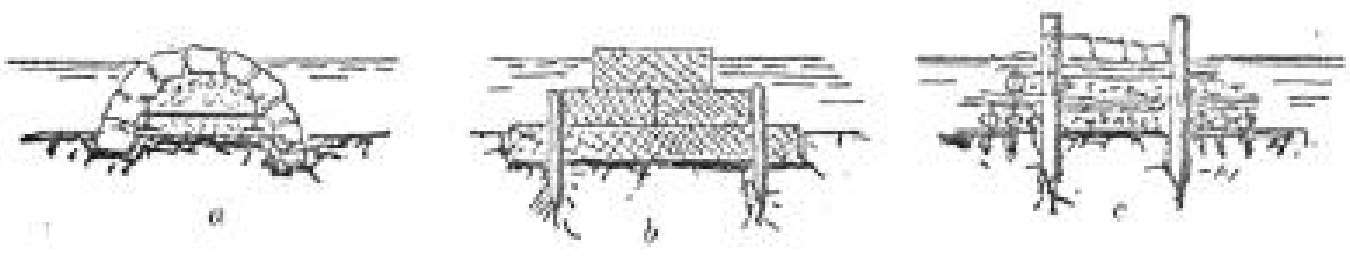

Fig. 11 - Groynes [Hofman 1936]

a) groynes with semi-cylinder section and reinforcement

b) metal gabions

c) wattling and stones. 
Benini [2000] sustains that groyne efficacy is within a distance of 5 times the protruding construction length.

\subsection{Log cribwall (also with branchlayers)}

Pareto [1886] reports examples of log revetments as proposed by sir Culmann for the Eschibach torrent control near Berna. They are constructions of interlocking locks into a crib, the bottom layer of logs are anchored into the bank.
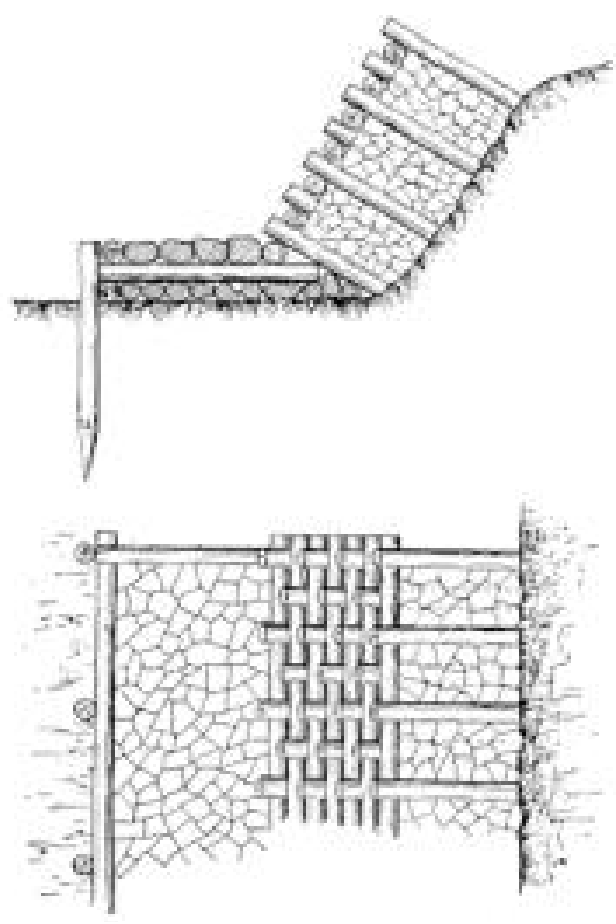

Fig. 12 - Log cribwall [Di Tella 1939].
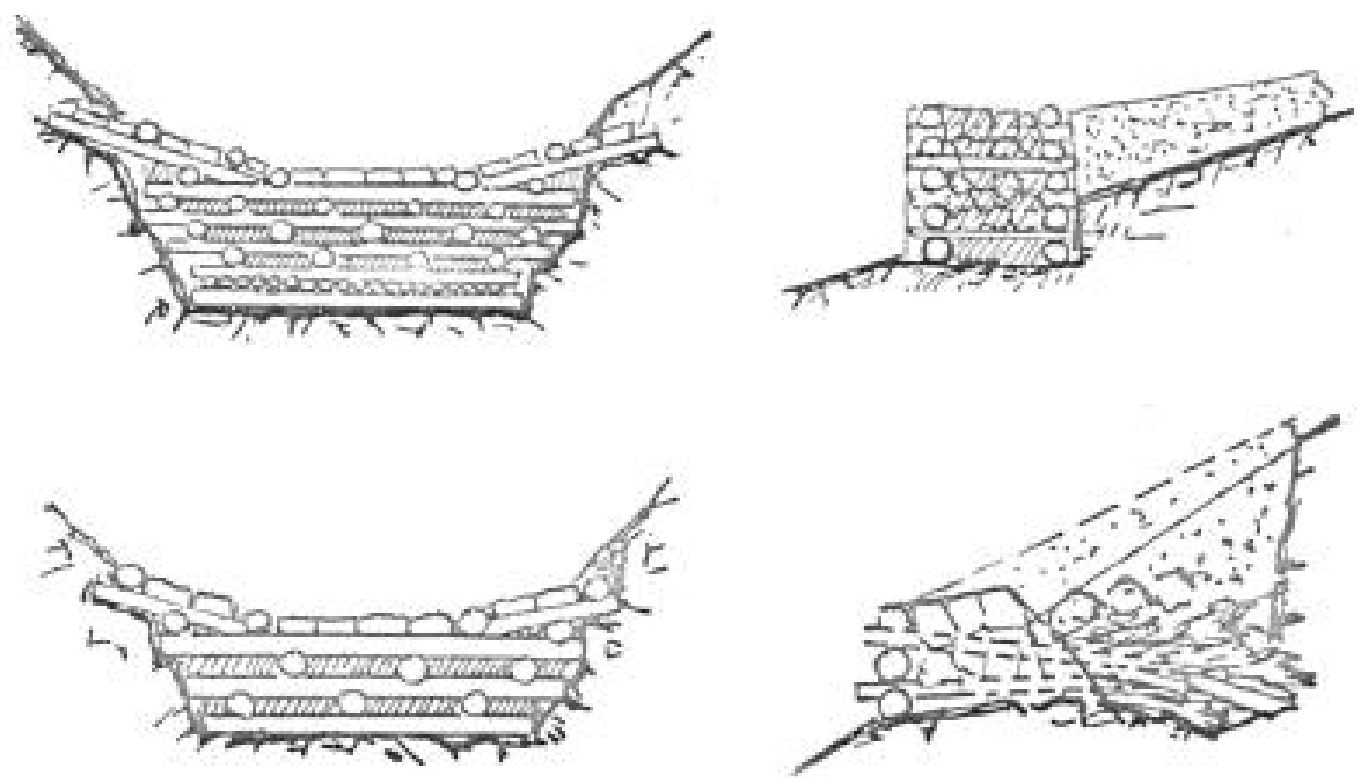

Valentini [1893] mentions the use, within the longitudinal defence works, of the log-rock revetments.

Di Tella [1939] also proposes, as defence works, a frame work of vertical posts deeply driven and linked with cross elements, filled with stones more or less regularly piled up.

Wang [1903] suggests, as longitudinal defence works, the use of a log cribwall with an anchor log and for their constrution he advises to refer to the indications given for the log check dams. He adds that to maintain that work solid, the side facing the water is renforced by poles, to avoid the breaking up of the structure under the filling material pressure.

Hofman [1936] reports the utilization of the $\log$ cribwall with brunchlayers as longitudinal work both for small dams and streambanks under erosion. For minor works, he suggests the use of the rock-filled log crib. He distinguishes between the rock-filled double $\log$ crib and the rock-filled log crib.

Hassenteufel in 1934 [Schiechtl 1991] utilized, for the first time, some willow branches instead of filling rocks for the Lussbach control nearby Lermoos, in Tirolo.

\subsection{Log check dams}

Valentini [1893] suggests the utilization of wood as construction material when stones are not available. Wooden crib dams with the frame work in wood filled with stones can be used.

Tornani [1895] suggests the use of wooden crib dams when heavy material is lacking, a framework of fir is formed and then is filled with dry stone masonry. It is important to outline that, already at that time, it was known that logs continuosly wet would maintain better than conditions of alternate wet and dry. This is the reason why the log check use is preferred

Fig. 13 - Mixed works [Hofman 1936]. 
for those torrents with a significant minimum flow.

Piccioli [1905] suggests the use of log checks where those materials are abundant. Fir or spruce trunks are utilized with all the branches. The dam consists in alternate layers of wood and stones, and each layer is kept together through pieces cross wide placed. The voids are filled with stones before proceeding with the next layer.

Valentini [1912] advises the log check dams when there is timber in abundance and stones are lacking. The log-check dams are realized with a framework in timber filled with stones.

Di Tella [1939] proposes the use of iron elements to connect the logs.

Hofman [1936] reports the description of small dams and sills utilized for some torrent control in the Alps, saying that the more common is the gabion filled with stones taken at the site. In some torrents, characterized by earth river bed, the timber may be also utilized and driven with all the branches.

\section{Results}

From the found text consultation, the presence of references to torrent control works utilizing vegetation since the ancient times appears. Living plants have been used for a very long time throughout the world in structures against soil erosion, as traces have been found dating back to the first century BC [Evette 2009]. Already Leonardo da Vinci wrote that the presence of willow on the slopes increased its stability because the roots did not allow slopes to break and its branches, being pruned, became stronger [Schlüter 1984]. For the selected works, the quotations have been translated into English through a chronological order to favour the comparison among the realization techniques and designing references. In table 1 , the text authors, the publication year and the work typology are reported only for those books in our possession. In the texts of late ' 800 , only references to some works are reported, such as log-rock vegetated revet- ment and groynes.

In texts of the first decades of ' 900 , as Viappiani [1923] and Hofman [1936], citations to some works are described. Among the vegetated works for embankment defending, references are found to the wattles and fascines, with indications to the dimensions of the vegetated elements to be utilized and the distances to be kept when constructing (tab. 2). Valentini, Wang, and Viappiani also give numerical references to the wattles. Wang [1903] proposes a detailed description of the fascine cylinders, filled with gravels. Among the works for the vegetated revetment of the embankments, descriptions with designing indications of the vegetated revetments are found in Valentini, Wang and Viappiani [1923]. Coming to actual texts, wide descriptions of both old interventions and new ones using new materials may be found.

In table 3 brush matress dimensions are reported from Wang [1903] and Schiechtl [1991].

The present paper deals only with stone and wood dams, which are always mentioned in river and soil bioengineering manuals (even if they are not "living" works) and which are among the most ancient and traditional works. Despite this, while for great sediment retention dams dimensioning criteria and desgn criteria tests have been clearly mentioned since the first years of the 20th century, as far as consolidation dams are concerned, information is more limited. Table 4 reports the data collected for this kind of work with the following symbols (we need to specify that some Authors do not make any distinctions between wood and stone dams and dams which, even with the same functions, are made of other materials such as dry stone, mortar, masonry, etc.).

It must be noted that none of the Authors point out which are the limits of the liquid and solid flow rate or the maximum area of the upstream watershed where the dams must be built. One limit is obviously given by the maximum dam's body height $\mathrm{H}$. In past times, structures up to $10 \mathrm{~m}$ high have been conjectured [Viappiani 1923; Di Tella and Bay 1939]: even supposing a $\mathrm{B} / \mathrm{H}=1$ ratio, it was unlikely to reach

\begin{tabular}{|c|c|c|c|c|c|c|}
\hline Author & Year & $\begin{array}{c}\text { Log-rock } \\
\text { check } \\
\text { dam }\end{array}$ & $\begin{array}{c}\text { Log-rock } \\
\text { bank } \\
\text { work }\end{array}$ & $\begin{array}{c}\text { Vegetated } \\
\text { bank } \\
\text { protection }\end{array}$ & Groynes & $\begin{array}{c}\text { Vegetated } \\
\text { revetment }\end{array}$ \\
\hline Pareto & 1850 & & $\times$ & & & \\
\hline Valentini & 1893 & & & $\times$ & & \\
\hline Tornani & 1895 & & $\times$ & & & \\
\hline Wang & 1903 & $\times$ & $\times$ & $\times$ & $\times$ & $\times$ \\
\hline Piccioli & 1905 & & & $\times$ & $\times$ & \\
\hline Valentini & 1912 & $\times$ & $\times$ & $\times$ & & \\
\hline Viappiani & 1915 & $\times$ & & $\times$ & $\times$ & $\times$ \\
\hline Hofman & 1936 & $\times$ & $\times$ & $\times$ & $\times$ & $\times$ \\
\hline Di Tella & 1939 & $\times$ & $\times$ & $\times$ & $\times$ & \\
\hline Schiechtl & 1991 & $\times$ & $\times$ & $\times$ & $\times$ & $\times$ \\
\hline
\end{tabular}

TABLE 1 - Stream works: historical view. 


\begin{tabular}{|c|c|c|c|c|c|c|c|}
\hline & & $\begin{array}{c}\text { Stake } \\
\text { diameter } \\
{[\mathrm{cm}]}\end{array}$ & $\begin{array}{c}\text { Stake } \\
\text { length } \\
{[\mathrm{cm}]}\end{array}$ & $\begin{array}{c}\text { Stake } \\
\text { distance } \\
{[\mathrm{cm}]}\end{array}$ & $\begin{array}{c}\text { Driven } \\
\text { depth }\end{array}$ & $\begin{array}{c}\text { Distance } \\
\text { between } \\
\text { rows } \\
{[\mathrm{cm}]}\end{array}$ & Vegetation \\
\hline Valentini & 1893 & & $\begin{array}{c}100 \\
33\end{array}$ & & & & $\begin{array}{c}\text { larch } \\
\text { willow }\end{array}$ \\
\hline Wang & 1903 & $10 \div 15$ & 100 & & $1 / 2$ & & \\
\hline Viappiani & 1923 & $4 \div 10$ & $60 \div 200$ & $20 \div 50$ & $6 / 10$ & $80 \div 100$ & $\begin{array}{l}\text { Twigs of } \\
\text { resinous trees } \\
\text { or willows }\end{array}$ \\
\hline Schiechtl & 1991 & $3 \div 10$ & 100 & 30 & $2 / 3$ & $120 \div 200$ & $\begin{array}{c}\text { Twigs of } \\
\text { flexible trees } \\
\text { with } \\
\text { vegetative } \\
\text { propagation } \\
\text { attitude }\end{array}$ \\
\hline
\end{tabular}

TABLE 2 - Stream wattling dimensions.

\begin{tabular}{|c|c|c|c|c|c|c|c|}
\hline \multicolumn{2}{|c|}{ Sapling } & \multicolumn{3}{c|}{ Anchorage stakes } \\
\hline Author & Year & $\begin{array}{c}\text { D } \\
{[\mathrm{cm}]}\end{array}$ & $\begin{array}{c}\text { Length } \\
{[\mathrm{cm}]}\end{array}$ & Density & $\begin{array}{c}\text { Length } \\
{[\mathrm{cm}]}\end{array}$ & $\begin{array}{c}\text { Driven } \\
\text { depth } \\
{[\mathrm{cm}]}\end{array}$ & $\begin{array}{c}\text { Log stake distance } \\
{[\mathrm{cm}]}\end{array}$ \\
\hline Wang & 1903 & 8 & & & $\begin{array}{c}150 \\
200\left(2^{\circ} \text { row }\right)\end{array}$ & 100 & 130 \\
\hline Schiechtl & 1991 & & 150 & $\begin{array}{c}20 \div 50 \\
\text { per meter }\end{array}$ & & & $\begin{array}{c}80 \div 100 \text { among rows } \\
60 \div 80 \text { on the same row }\end{array}$ \\
\hline
\end{tabular}

TABLE 3 - Brush mattress dimensions.

these heights, while today it is recommended not to be over 3 meters in the weir height. Note that the base thickness height ratio $(\mathrm{B} / \mathrm{H})$ is always near to 1 . In wood and stone dams designing, the rules concerning dimensioning usually derive direclty from experience. In time, a rule was established according to which, in order to achieve an adequate stability of the crib wall dams, it was enough to establish a base length equivalent to half the height (the height is determined once the bed stabilization slope and the number of dams are established). Nevertheless, as pointed out in table 4, in all the texts published from 1915 to 1939 , Authors were more inclined to fix a base thickness approximately equal to the height (fig. 13). Recent studies, demonstrated how, in case of drained dams, the choice of a base thickness/height ratio equal to 1 is always in favour of safety, while stability conditions are not always achieved with $\mathrm{B}=\mathrm{H} / 2$.

Among the large variety of techniques discussed in this article, some are still being used unchanged, and still others have evolved significantly. In fact the recent appearance of new materials (e.g. iron mesh, geotextiles, geogrids, or plastic geocells) and technologies (e.g. mechanical excavator, electric drill and chain saw) led to the development of new techniques and easier implementation [Evette 2009]. "Hard" engineering techniques have been preferred to stabilize the beds of rivers and torrents at the end of last century, due to the availability of new materials, transportation and mechanization and to manpower cost increase [Petrone 2008].

Finally, it has to be noticed that bioengineering techniques may also have been used in the past for functions other than river and soil stabilization (such as improving habitat quality in in-stream fisheries, basketry, medicinal production, etc.) and today, they are also a useful tool for restoring the degraded ecological habitats of riverbanks and in landscape restoration projects [Evette 2009]. 


\begin{tabular}{|c|c|c|c|c|c|c|c|}
\hline$\frac{\dot{e}}{E}$ & 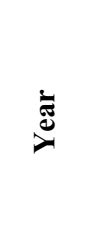 & 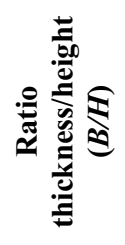 & 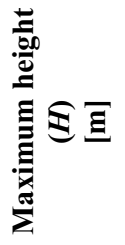 & 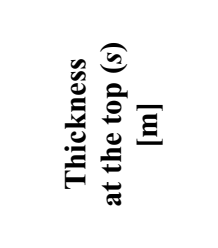 & 量量司 & 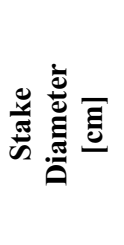 & 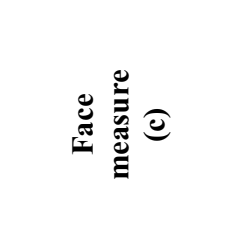 \\
\hline Valentini & 1912 & $\approx 1$ & 10 & $\begin{array}{c}s=B-0.53 h^{0.5} \\
\text { in any case: } \\
\mathrm{s}>0.6 h\end{array}$ & & & $\begin{array}{c}\text { For } \mathrm{H}<4.5 \mathrm{~m} \\
\mathrm{c}=0.25 \mathrm{H} \\
\text { For } 4.5<\mathrm{H}<10 \\
\mathrm{c}=0.20 \mathrm{H}\end{array}$ \\
\hline Viappiani & 1923 & $\approx 1$ & 10 & & & & \\
\hline De Horatiis & 1930 & 1 & & $\begin{array}{c}S=B-0.5 h^{0.5} \\
\text { in any case: } \\
\mathrm{s}>0.6 h\end{array}$ & & & $c=0.5 h^{0.5}$ \\
\hline Hofmann & 1936 & $1^{*}$ & $2 \div 4$ & & $30 * *$ & & \\
\hline $\begin{array}{l}\text { Di Tella e } \\
\text { Bay }\end{array}$ & 1939 & $\approx 1$ & 10 & $\begin{array}{c}s=B-0.53 h^{0.5} \\
\text { in any case: } \\
\mathrm{s}>0.6 h\end{array}$ & $30 * * *$ & & $\begin{array}{l}c=1 / 4 \text { for } \mathrm{H} \leq 4.5 \\
c=1 / 5 \text { for } \mathrm{H}>4.5\end{array}$ \\
\hline Schiechtl & 1991 & $0.5 \div 1$ & 5 & & & $15 \div 20$ & \\
\hline
\end{tabular}

TABLE 4 - Log check dam dimensions (from Bresci and Preti 2001).

$h=$ water height over the weir; $c=$ upstream face cotg(slope angle): $s=$ dam's body thickness; $H=$ dam's body height; $B=$ base of the dam's body witdh: $B=s+c H$; *calculated from the drawings proposed in the text; ** larch, pine, chestnut; $10-$ 15 fir, minimum: beech, sizable: alder, oak.; *** larch, black pine, chestnut, 12 -15: fir, minimum: beech.

\section{Conclusions}

In this paper (Part II) and in the previous one (Part I), a comparison between the forest watershed management works (torrent control and soil conservation) and the so-called soil bioengineering techniques has been carried out.

The individuation and the transcription of the original texts which described the selected interventions, allowed the analysis of their evolution and reintroduction over the years. It led us to claim that river and soil bioengineering, sometimes erroneously or speciously regarded as a recent discipline, today represents the renovation and the improvement of building concepts and techniques in use since the remote past in those environments where the only available and usable building materials were those found in situ [Bresci 2001]. Widely practiced during the eighteenth and nineteenth centuries, river and soil bioengineering was somewhat abandoned in the middle of the twentieth century, before seeing a resurgence in recent times [Evette 2009].

Today, available technical manuals and regulations spurs suggest and prefer river and soil bioengineering interventions, especially from a social-environmental point of view and when the safety requirements and real possibilities allow their use. Very often, river bioengineering work combines several techniques, to at- tain precise objectives corresponding both to environmental factors and mechanical constraints [Evette 2009].

Also in this case (Part II), it is confirmed that river and soil bioengineering techniques clearly originate from forest watershed management, as clearly demonstrated by classic biographical sources.

\section{Acknowledgments}

The authors want to remember Prof. eng. Silvano Grazi for his contribution in the sector and sincerely thank Prof. eng Virgilio Anselmo for having reviewed the manuscript.

\section{References}

Alberti G.A., Istruzioni pratiche per l'ingegnero civile o sia perito agrimensore e perito d'acque. Pietro Savioni, 1799, Venezia.

Anselmo V., L'Ingegneria naturalistica nella pratica professionale. In Le sistemazioni idraulico-forestali con tecniche di ingegneria naturalistica - Quaderni di Idronomia montana 28/3, Editoriale Bios, 2008, Cosenza.

Benini G., Sistemazioni idraulico-forestali. 2000, UTET, Torino. 
Bischetti G.B., D’Agostino V., Ferro V., Gentile F., Preti F., Tecniche di Ingegneria naturalistica e Sistemazioni idraulico-forestali. In Le sistemazioni idraulico-forestali con tecniche di ingegneria naturalistica - Quaderni di Idronomia montana 28/3, Editoriale Bios, 2008, Cosenza.

Bresci E., Preti F., Alcuni spunti per un'analisi comparata fra sistemazioni idraulico-forestali e ingegneria naturalistica. Convengo AIIA: Ingegneria Agraria per lo sviluppo dei paesi del mediterraneo Vieste (Fg), 2001. 11-14 settembre.

Bresci E., Preti F., Un'indagine storica sull'evoluzione di alcune tecniche di sistemazione idraulico-forestale (interventi su versante). Rivista di Ingegneria Agraria, 2002, 1, 35-44.

Grazi S., Appunti delle lezioni di Idronomia Montana (Sistemazioni Idraulico-Forestali). CLUSF - Cooperativa Editrice Universitaria Firenze, 1980, Firenze.

De Maria V., Studio su i torrenti. Mezzi da impiegarsi per regolarli ed estinguerli. Tipi Pontieri, fuori Portamedina 27 e 28, 1894, Napoli.

Demontzey P., Traité pratique du reboisement et du gazonnement des montagnes. 1882, Paris.

Di Tella G., Bay F., Le correzioni dei torrenti. S.A.G. Barbera, 1939, Ed. Firenze.

Evette A., Labonne S., Rey F., Liebault F., Jancke O. and Girel J., History of Bioengineering Techniques for Erosion Control in Rivers in Western Europe. Environmental Management, 2009, 43, 972-984.

Hofman A., La sistemazione idraulica-forestale dei bacini montani. UTET, 1936, Torino.

Lanino L., Corso di costruzioni stradali e idrauliche. Unione Tipografico-Editrice, 1898, Torino.

Pareto R., Sui torrenti, burroni e frane. Tipografia degli Ingegneri, 1866, Milano.

Piccioli F., Boschi e Torrenti. Casa Editrice Nazionale, 1905, Roma-Torino.

Petrone A., Preti F., Suitability of soil bioengineering techniques in Central America: a case study in Nicaragua. Hydrol. Earth Syst. Sci., 2008, 12, 1241-1248, www.hydrol-earth-syst-sci.net/12/1241/2008/

Preti F., Bresci E., Un confronto storico fra "Sistemazioni Idraulico-Forestali" e "Ingegneria Naturalistica" Convegno su "Ingegneria Naturalistica: dal Progetto ai Risultati”. CUSL, 2004, Milano, 135 $\div 143$.

Schemerl di Leytenbach G., Del miglior modo di costruire ripari sui torrenti. Francesco Andreola, 1818, Venezia.

Schiechtl H.M., Bioingegneria Forestale - Biotecnica naturalistica. Edizioni Castaldi, 1991, Feltre.
Schlüter U., Zur Geschichte der Ingenieurbiologie. Landschaft und Stadt, 1984, Heft 16(1/2), S. 2-9.

Sganzin G.M., Pubbliche Costruzioni. Nell'I.R. Privil. Stabilimento Antonelli Editore, 1847, Venezia.

Tornani I., Sanjust di Teulada E., Pasini P., D’Urso F., Sulla correzione dei torrenti nella Svizzera nella Francia e nella Corinzia. Tipog. e Litog. del Genio Civile, 1895, Roma.

Valentini C., Sulla sistemazione dei torrenti. Stabilimento tipo-litografico del Genio Civile, 1893, Roma.

Valentini C., Sistemazione dei torrenti e dei bacini montani. Ulrico Hoepli - Editore, 1912, Milano.

Viappiani A., Trattato di Idraulica Applicata. Ulrico Hoepli - Editore, 1923, Milano.

Viviani V., Discorso intorno al difendersi dai riempimenti e corrosioni dei fiumi applicato ad Arno in vicinanza della città di Firenze, 1864, Firenze.

Wang F., Grundriss der Wildbachverbauung. Verlag von S. Hirzel, 1903, Leipzig.

\section{SUMMARY}

Quotations and references, taken from old texts on stream channel works (today classified as belonging to soil bioengineering interventions), are presented and discussed. Part I of the same study previously showed a similar analysis on slope stabilization [Bresci 2002]. The selected quotations are reported in a chronologic order to highlight the historical evolution in each work description and, in particular, the instructions and adjustments to put on when carried out. Where suggestions for vegetation material selection and numerical indications are found in the analyzed texts, they have been reported translated into English. The selection of the analyzed works has been carried out among those utilized for streambank protection, a sector where more often vegetation is utilized. Also in this case (Part II) it is demonstrated that bioengineering techniques clearly originate from forest watershed management.

Keywords: Watershed management, bioengineering, vegetated streambank protection, log check dam, groynes. 